\title{
The Relationship Between Disease Activity, Vegf, E-selectin Levels and Arterial Stiffness in Patients with Rheumatic Diseases
}

\author{
Romatizmal Hastalığı Bulunan Hastalarda Arteriyel Sertlik, Vegf ve E-selektin Düzeyi \\ ile Hastalık Aktivitesi Arasındaki İlişki
}

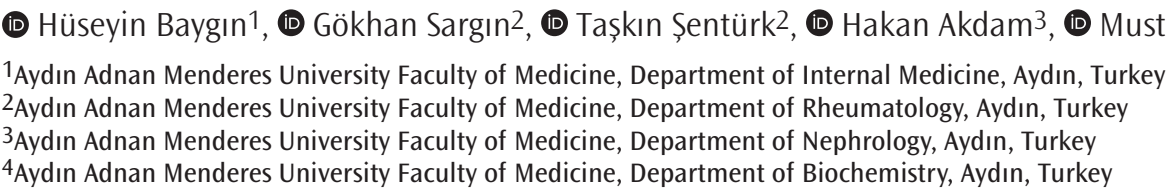

\begin{abstract}
Introduction: The endothelial damage, changes in vascular permeability and plaque formation are caused by the effects of cytokines and chemokines that plays role in chronic inflammation in rheumatoid arthritis (RA) and ankylosing spondylitis (AS). It has been reported that arterial stiffness and the level of cell adhesion molecules are affected by inflammation. In this study, we aimed to determine the relationship between vascular endothelial growth factor (VEGF), E-selectin, arterial stiffness and disease activity in patients with rheumatic diseases.
\end{abstract}

Methods: Thirteen patients diagnosed with AS, 28 patients diagnosed with RA and 30 healthy controls were included in the study. Arterial stiffness, VEGF, E-selectin, erythrocyte sedimentation rate (ESR) and C-reactive protein (CRP) were evaluated in all patients and healthy controls. Bath Ankylosing Spondylitis Disease Activity Index (BASDAI) and Disease Activity Score-28 (DAS-28) were calculated in patients with rheumatic diseases. The level of serum VEGF and E-selectin were determined by ELISA, and arterial stiffness was measured by oscillometric method. The data were statistically evaluated by using Student t-test, Mann-Whitney U Test and Wilcoxon test.

Results: DAS-28, BASDAI, ESR and CRP levels were significantly decreased on the $3^{\text {rd }}$ month of treatment in all patients $(p<0.001)$. VEGF and E-selectin levels increased, and pulse wave velocity (PWV) and augmentation index (Alx) parameters decreased with treatment. While the level of PWV did not change, Alx decreased on the $3^{\text {rd }}$ month of non- tumor necrosis factor treatment in RA patients.

Conclusion: DAS, ESR and CRP were decreased with the reduction of inflammation in RA and AS patients with treatment. PWV and Alx of arterial stiffness parameters decreased after 3 months of treatment, but it did not reach statistical significance. Arterial stiffness and cardiovascular risk are expected to reduce significantly with ongoing treatment process.

Keywords: Rheumatoid arthritis, ankylosing spondylitis, arterial stiffness, vascular endothelial growth factor, E-selectin, disease activity

\section{ÖZ}

Amaç: Romatoid artrit (RA) ve anklozan spondilitte (AS) endotel hasarı, damar geçirgenliğinde değişim, plak oluşumu kronik enflamasyonda rolleri olan sitokin ve kemokinlerin etkisi ile olmaktadır. Yapılan çalıșmalarda enflamasyon düzeyi ile arteryel sertlik ve hücre adezyon molekül miktarında değişim olduğu bildirilmiștir. Bu çalıșmada, romatizmal hastalığı olan hastalarda vasküler endotel büyüme faktörü (VEGF), E-selectin, arteriyel sertlik ve hastalık aktivitesi arasındaki ilişkiyi belirlemeyi amaçladık.

Yöntemler: Çalışmamıza AS tanılı 13 hasta, RA tanılı 28 hasta ve 30 sağlıklı kontrol dahil edildi. Tüm hasta ve sağlıklı kontrol grubunda arteriyel sertlik, VEGF ve E-selektin, eritrosit sedimentasyon hızı (ESH) ve CRP düzeylerine bakıldı. Romatizmal hastalığı bulunan grupta hastalık aktivite göstergeleri olan Banyo Ankilozan Spondilit Hastalığı Aktivite İndeksi (BASDAi) ve DAS-28 skorları hesaplandı. Serum VEGF ve E-selektin ölçümü ELISA yöntemi ile, arteriyel sertlik ölçümü ise osilometrik metotla bakıldı. Elde edilen veriler Student t-testi, Mann-Whitney U testi ve Wilcoxon testi ile istatistiksel olarak karşılaștırıldı.

Bulgular: Tüm hasta gruplarında tedavi sonrasında 3. ayda DAS-28, BASDAi skorları, ESH ve CRP düzeylerinde anlamlı bir azalma olduğu gözlenmiștir $(p<0,001)$. Tedavi ile birlikte VEGF ve E-selektin düzeylerinde artış, nabız dalga hızı (NDH) ve artırma indeksi (Alx) parametrelerinde ise azalma olduğu gözlenmiștir. Non-tümör nekroz faktörü tedavisi alan RA hastalarında NDH düzeyi değișmezken, Alx düzeyi tedavinin 3. ayında azalmıştır.

Sonuç: RA ve AS hastalarında tedavi ile birlikte inflamasyonun azalması hastalık aktivite skorunda, ESH, CRP değerlerini azaltmaktadır. Arteryel sertlik parametrelerinden $\mathrm{NDH}$ ve Alx’i tedavinin 3. ayında azalma ile birlikte anlamlı düzeye ulașmamıştır. Devam eden tedavi sürecinde arteryel sertliğin ve kardiovasküler riskin anlamlı düzeyde azalacağı düşünülmektedir.

Anahtar Kelimeler: Romatoid artrit, ankilozan spondilit, arteriyel sertlik, vasküler endotelyal growth faktör, e-selektin, hastalık aktivitesi
Address for Correspondence/Yazıșma Adresi: Hüseyin Baygın MD, Aydın Adnan Menderes University Faculty of Medicine, Department of Internal Medicine, Aydın, Turkey

Phone: +90 5393772398 E-mail: bayginhuseyin@hotmail.com ORCID ID: orcid.org/0000-0002-7394-6476

Cite this article as/Atıf: Baygın H, Sargın G, Şentürk T, Akdam H, Yılmaz M. The Relationship Between Disease Activity, Vegf, E-selectin Levels and Arterial Stiffness in Patients with Rheumatic Diseases. İstanbul Med J 2019; 20(4): 285-8.
Received/Geliș Tarihi: 04.03.2019 Iccepted/Kabul Tarihi: 29.05.2019 


\section{Introduction}

Rheumatic diseases such as rheumatoid arthritis (RA) and ankylosing spondylitis (AS) can cause morbidity with extra-articular involvement. Various cytokines involved in RA pathogenesis lead to synovial cell proliferation, expression of endothelial adhesion molecules and collagen production. Rapid atherosclerosis and increased risk of cardiovascular disease are also mentioned in AS and RA patients, and inflammatory processes have an important role (1-3). Atherosclerosis is more common in RA patients than in the general population $(1,2)$. Arterial stiffness is a condition that leads to decreased expansion capacity of the vessels in response to pressure changes. Arterial stiffness is an independent risk factor for cardiovascular disease and can be used as an indicator of subclinical cardiac injury $(4,5)$.

It is known that angiogenesis and angiogenetic factors play a role in the development of rheumatic diseases. Vascular endothelial growth factor (VEGF) is a potent angiogenic factor and oversecretion can lead to the development of many pathological conditions such as atherosclerosis, age-related macular degeneration, RA and diabetic retinopathy $(6,7)$. E-selectin (CD62E), a cell adhesion molecule expressed in endothelial cells, plays a mediator role in the interaction between vascular endothelium and circulating leukocytes in many pathophysiological conditions such as inflammation, infection and cancer metastasis. This interaction is an important part of various pathophysiological processes such as inflammation and atherosclerosis (8).

In this study, we aimed to present the relationship between disease activation, arterial stiffness and changes in the level of cell adhesion molecules in patients diagnosed with RA and AS.

\section{Methods}

Forty-one patients (28 RA and 13 AS) (BASDAI $>5$ and DAS28>5.1) with rheumatic disease and 30 healthy controls were included in the study. AS was diagnosed according to the axial spondyloarthritis classification criteria and RA was diagnosed using 2010 ACR/EULAR 2010 classification criteria $(9,10)$. Regarding healthy controls, subjects with rheumatologic or other concomitant conditions (hypertension, diabetes mellitus, chronic renal failure, liver disease, hypo-hyperthyroidism, chronic obstructive pulmonary disease, peripheral arterial disease, coronary artery disease, malignancy) were excluded from the study. Demographic and laboratory features of the patients were recorded. Informed consent form was signed by all participants. Adnan Menderes University Faculty of Medicine, Non-invasive Clinical Research Ethics Committee (decision no: 2015/739, date: 25.12.2015).

VEGF and E-selectin were measured with human ELISA kit (SunRed Biological Technology, Shanghai, China). Standard solutions of 75, 150,
300, 600, $1200 \mathrm{ng} / \mathrm{L}$ were prepared using the stock standard solution in the kit. $50 \mu \mathrm{L}$ control, standard and samples were placed in antibodycoated wells in the plate, respectively. $50 \mu \mathrm{L}$ chromogen/substrate solution was placed in all wells and kept at $37^{\circ} \mathrm{C}$ for 10 minutes without light. ELISA (DAR 800, Diagnostic Automation, California, USA) was automatically calculated at $450 \mathrm{~nm}$ with the help of standard solutions prepared using a microplate reader.

Arterial stiffness was measured by using a single cuffed oscillometric "arteriograph device". Patients were rested for at least 5 minutes before measurement and were asked not to smoke or drink caffeinated beverages at least 30 minutes before. The cuff of the device was adjusted to fit in the position and at the heart level, and 3 consecutive measurements were taken automatically for 30 seconds. The augmentation index (Alx) and pulse wave velocity (PWV) levels were measured by a computer.

\section{Statistical Analysis}

The data were evaluated using SPSS version 22 statistical program. Descriptive data were expressed as mean, standard deviation, median, minimum, maximum and percentage. The obtained data were statistically compared with Student's t-test, Mann-Whitney $U$ test and Wilcoxon test. A p value less than 0.05 was considered statistically significant.

\section{Results}

Forty-one patients and 30 healthy controls were included in this study. There were 28 patients (68.3\%) diagnosed with RA and 13 patients (31.7\%) diagnosed with AS. Fourteen patients (34.1\%) were male and $27(65.9 \%)$ were female. The mean age was $51.0 \pm 12.1$ years (range: $27-$ 74 years). In the control group, 10 subjects (33.3\%) were male and 20 (66.7\%) were female. The mean age was $51.9 \pm 10.8$ (range: $29-71$ years). The mean body mass index (BMI) of the patients was $30.7 \pm 6.5$, while the mean BMI of the control group was $29.5 \pm 3.9$. There was no statistically significant difference between patients and control groups in terms of age and BMI $(p>0.05)$. Twenty-eight patients were using anti-tumor necrosis factor (anti-TNF) and the remaining 13 patients were using nonTNF biological agents.

A statistically significant decrease in DAS-28, BASDAI, erythrocyte sedimentation rate (ESR) and C-Reaktif Protein (CRP) levels were observed in all patients after 3 months of treatment. The pre- and post-treatment median levels of E-selectin ( $359.5 \mathrm{ng} / \mathrm{L}$ vs $386.5 \mathrm{ng} / \mathrm{L}, \mathrm{p}=0.311$ ) and VEGF (956.5 ng/L vs $1093.5 \mathrm{ng} / \mathrm{L}, \mathrm{p}=0.046$ ) in RA patients are shown in Table 1. The post-treatment median levels of E-selectin $(414.0 \mathrm{ng} / \mathrm{L}$ vs $393.0 \mathrm{ng} / \mathrm{L}$, $\mathrm{p}=0.724)$ and VEGF (1035.0 ng/L vs $1028.0 \mathrm{ng} / \mathrm{L}, \mathrm{p}=0.422)$ were increased in the AS patients (Table 1). Despite a slight decrease in E-selectin levels and a slight increase in VEGF levels after treatment, there was no

\section{Table 1. Serum E-selectin and vascular endothelial growth factor levels in rheumatoid arthritis and ankylosing spondylitis patients}

\begin{tabular}{|c|c|c|c|c|c|c|}
\hline & \multicolumn{3}{|l|}{ Rheumatoid arthritis } & \multicolumn{3}{|l|}{ Ankylosing spondylitis } \\
\hline & Pre-treatment (ng/L) & $\begin{array}{l}\text { Post-treatment } 3^{\text {rd }} \text { month } \\
\text { (ng/L) }\end{array}$ & p-value & Pre-treatment (ng/L) & $\begin{array}{l}\text { Post-treatment } 3^{\text {rd }} \text { month } \\
\text { (ng/L) }\end{array}$ & p-value \\
\hline E-selectin & 359.5 & 386.5 & 0.311 & 393.0 & 414.0 & 0.724 \\
\hline VEGF & 956.5 & 1093.5 & 0.046 & 1028.0 & 1035.0 & 0.422 \\
\hline
\end{tabular}


Table 2. Arterial stiffness parameters in rheumatoid arthritis and ankylosing spondylitis patients

\begin{tabular}{|l|l|l|l|l|l|}
\hline & \multicolumn{2}{|c|}{ Rheumatoid arthritis } & \multicolumn{3}{c|}{ Ankylosing spondylitis } \\
\hline & $\begin{array}{l}\text { Pre-treatment } \\
\text { (ng/L) }\end{array}$ & $\begin{array}{l}\text { Post-treatment 3 } \\
\text { (ng/L) }\end{array}$ & p-value & $\begin{array}{l}\text { Pre-treatment } \\
\text { (ng/L) }\end{array}$ & $\begin{array}{l}\text { Post-treatment 3 } \\
\text { (ng/L) }\end{array}$ \\
\hline Alx & $28.8 \pm 9.0$ & $26.7 \pm 10.7$ & 0.217 & $27.4 \pm 8.2$ & $27.7 \pm 10.9$ \\
\hline PWV & $8.0 \pm 1.5$ & $7.9 \pm 1.6$ & 0.553 & $6.4 \pm 0.9$ & $6.3 \pm 0.8$ \\
\hline Alx: augmentation index, PWV: pulse wave velocity & & & & 0.927 \\
\hline
\end{tabular}

statistically significant difference in E-selectin and VEGF levels between anti-TNF or non-TNF treatment in both AS and RA patients. A statistically significant difference was not detected in the parameters of Alx and PWV before and after 3 months of treatment in RA and AS patients (Table 2).

\section{Discussion}

VEGF is an angiogenic cytokine that plays a role in angiogenesis, and also stimulates the migration and proliferation of endothelial cells (6). Serum and synovial fluid VEGF levels in RA patients were found to be higher than patients with osteoarthritis systemic lupus erythematosus and scleroderma, and healthy subjects $(11,12)$. Serum VEGF levels were found to be higher in AS patients compared to healthy controls (13). In our study, we did not find any significant difference between AS and healthy control group in terms of serum VEGF level. In our study, VEGF levels were significantly lower in the patient groups than in the control group, whereas there was no statistically significant difference between AS and RA patients.

Serum VEGF levels have been reported to decrease in patients with AS treated with infliximab (14). Selaas et al. (15) found a decrease in VEGF levels on the $3^{\text {rd }}, 6^{\text {th }}$ and $12^{\text {th }}$ months in RA patients treated with infliximab. In our study, VEGF levels were increased on the $3^{\text {rd }}$ month of treatment, but there was no statistically significant difference compared to baseline. Positive correlation between VEGF levels, CRP and BASDAI was reported in 201 AS patients treated with infliximab (14). In our study, AS patients showed a significant decrease in BASDAI, CRP, and ESR values 3 months after treatment. On the other hand, there was no significant difference in VEGF levels compared to pretreatment levels.

E-selectin is a cell adhesion molecule expressed on the endothelial surface in response to proinflammatory cytokines (8). E-selectin levels were investigated and no significant differences were found between the control group and AS patients (16). In a study by Baeten et al. (17), 21 patients with spondyloarthropathy were treated with anti-TNF therapy and it was reported that E-selectin levels remained unchanged in synovial examination 12 weeks after treatment. It was reported that there was no change in E-selectin and VEGF levels at the end of 14 weeks in RA patients receiving TNF-alpha $(\alpha)$ blockade (18). In our study, E-selectin levels did not differ significantly in both AS and RA patients compared with control group. The cause of subclinical atherosclerosis may be due to platelet parameters, which are another important component in the atherosclerotic process because AS patients have normal endothelial function (19). We also found no significant difference in E-Selectin levels between all patients with rheumatic disease and control group.
Arterial stiffness is a structural change in the arterial wall caused by increase in PWV. PWV is widely accepted as an accurate and non-invasive method for assessing arterial stiffness. Even though PWV is a direct measurement of arterial flexibility, Alx is a more complex parameter of vascular elasticity and peripheral resistance. PWV and Alx are considered independent predictors of major cardiovascular events and all-cause mortality (20). Studies have shown that arterial stiffness is increased in RA patients compared to the control group; this may contribute to increased cardiovascular risk by accelerating the atherosclerotic process $(21,22)$. In our study, there was no significant difference in PWV and Alx parameters between RA patients and control group. Even though we observed a decrease in PWV and Alx parameters in all patient groups on the $3^{\text {rd }}$ month of treatment. This decrease was not significant compared to the baseline.

We found no significant difference in the levels of Alx and PWV in RA patients treated with infliximab compared to control group. In another study comparing etanercept with methotrexate, Alx was measured on the $2^{\text {nd }}$ and $4^{\text {th }}$ month. It was found that Alx improved in the etanercept group and remained unchanged in the methotrexate group (23). Different results obtained from different studies suggest that these may be related to the lack of direct measurement of arterial stiffness, differences in the reflectance of peripheral in RA patients and also other poorly understood concomitant factors (22).

There are inconsistent results in the literature regarding arterial stiffness in AS patients compared with the control group. In one study, no significant difference was found in arterial stiffness between AS patients and the control group. Avram et al. (24) compared 24 AS patients with 24 controls and found that Alx and PWV levels were significantly higher in the patient group. In our study, PWV levels were significantly lower in patients with AS than in the control group. On the other hand, there was no significant difference in Alx levels between the control group and AS patient group. In AS patients, Alx value increased from $27.4 \pm 8.2$ to $27.7 \pm 10.9$ on the $3^{\text {rd }}$ month of treatment. However, this increase was not statistically significant.

Although systemic inflammation is the primary cause of increased atherosclerosis in AS patients, the role of inflammation in stiffness of arteries is still unclear (24). When we compared Alx and PWV levels in all patient groups with the control group, we did not find any significant difference. In all patient groups, there was a significant decrease in disease activity score, sedimentation and CRP values at 3-month values after biological agent treatment. Despite the difference in Alx and PWV levels with biochemical treatment, it was not statistically significant. The main limitation of this study is that we have no information about the long-term effect of anti-TNF agents on these parameters. Another limitation is the small sample size. 


\section{Conclusion}

In our study, there were no significant difference in the levels of E-selectin and VEGF, Alx and PWV parameters in AS patients treated with biological agents compared with pre-treatment levels. The comparison between RA and AS patients showed no significant difference in terms of VEGF, E-selectin, and also PWV and Alx. It was shown that both PWV and Alx values decreased insignificantly in RA patients who received biological treatment. PWV levels remained unchanged in RA patients receiving non-TNF- $\alpha$ biotherapy, but Alx levels decreased in the $3^{\text {rd }}$ month of treatment. Reduction of the inflammatory process with treatment is thought to cause a decrease in the arterial stiffness, which is an important risk factor for cardiovascular diseases.

Ethics Committee Approval: Adnan Menderes University Faculty of Medicine, Non-interventional Clinical Research Ethics Committee (decision no: 2015/739).

Informed Consent: informed consent form was obtained.

Peer-review: Internally peer-reviewed.

Author Contributions: Design - H.B., G.S., T.S., H.A., M.Y.; Supervision H.B., T.Ş., G.S.; Data Collection and/or Processing - H.B., G.S., T.S., H.A.; Analysis and/or Interpretation - H.B., G.S., T.S., H.A., M.Y.; Literature Search - H.B., G.S., T.S., H.A., M.Y.; Writing Manuscript - H.B., G.S., T.S., H.A., M.Y.; Critical Review - H.B., G.S., T.Ş., H.A., M.Y.

Conflict of Interest: No conflict of interest was declared by the authors.

Financial Disclosure: The authors declared that this study received no financial support.

\section{REFERENCES}

1. Skeoch S, Bruce IN. Atherosclerosis in rheumatoid arthritis: is it all about inflammation? Nat Rev Rheumatol 2015; 11: 390-400.

2. Crowson CS, Liao KP, Davis JM 3rd, Solomon DH, Matteson EL, Knutson KL, et al. Rheumatoid arthritis and cardiovascular disease. Am Heart J 2013; 16: 622-8.

3. Genre F, López-Mejías R, Miranda-Filloy JA, Ubilla B, Carnero-López B, Blanco $\mathrm{R}$, et al. Adipokines, biomarkers of endothelial activation, and metabolic syndrome in patients with ankylosing spondylitis. Biomed Res Int 2014; 2014: 860651.

4. Teixeira R, Vieira MJ, Gonçalves A, Cardim N, Gonçalves L. Ultrasonographic vascular mechanics to assess arterial stiffness: a review. Eur Heart J Cardiovasc Imaging 2016; 17: 233-46.

5. Mathieu S, Joly H, Baron G, Tournadre A, Dubost JJ, Ristori JM, et al. Trend towards increased arterial stiffness or intima-media thickness in ankylosing spondylitis patients without clinically evident cardiovascular disease. Rheumatology (Oxford) 2008; 47: 1203-7.

6. Crafts TD, Jensen AR, Blocher-Smith EC, Markel TA. Vascular endothelial growth factor: therapeutic possibilities and challenges for the treatment of ischemia. Cytokine 2015; 71: 385-93.

7. Mapp PI, Walsh DA. Mechanisms and targets of angiogenesis and nerve growth in osteoarthritis. Nat Rev Rheumatol 2012; 8: 390-8.

8. Jubeli E, Moine L, Vergnaud-Gauduchon J, Barratt G. E-selectin as a target for drug delivery and molecular imaging. J Control Release 2012; 158: 194-206.
9. Schneider M, Krüger K. Rheumatoid arthritis--early diagnosis and disease management. Dtsch Arztebl Int 2013; 110: 477-84.

10. Ghasemi-Rad M, Attaya H, Lesha E, Vegh A, Maleki-Miandoab T, Nosair E, et al. Ankylosing spondylitis: A state of the art factual backbone. World J Radiol 2015; 7: 236-52.

11. Koch AE, Harlow LA, Haines GK, Amento EP, Unemori EN, Wong WL, et al. Vascular endothelial growth factor. A cytokine modulating endothelial function in rheumatoid arthritis. J Immunol 1994; 152: 4149-56.

12. Harada M, Mitsuyama K, Yoshida H, Sakisaka S, Taniguchi E, Kawaguchi T, et al. Vascular endothelial growth factor in patients with rheumatoid arthritis. Scand J Rheumatol 1998; 27: 377-80.

13. Drouart M, Saas P, Billot M, Cedoz JP, Tiberghien P, Wendling D, et al. High serum vascular endothelial growth factor correlates with disease activity of spondylarthropathies. Clin Exp Immunol 2003; 132: 158-62.

14. Visvanathan S, Wagner C, Marini JC, Baker D, Gathany T, Han J, et al. Inflammatory biomarkers, disease activity and spinal disease measures in patients with ankylosing spondylitis after treatment with infliximab. Ann Rheum Dis 2008; 67: 511-7.

15. Selaas O, Nordal HH, Halse AK, Brun JG, Jonsson R, Brokstad KA. Serum Markers in Rheumatoid Arthritis: A Longitudinal study of patients undergoing infliximab Treatment. Int J Rheumatol 2015; 2015: 276815.

16. Sari I, Alacacioglu A, Kebapcilar L, Taylan A, Bilgir O, Yildiz Y, et al. Assessment of soluble cell adhesion molecules and soluble CD40 ligand levels in ankylosing spondylitis. Joint Bone Spine 2010; 77: 85-7.

17. Baeten D, Kruithof E, Van den Bosch F, Demetter P, Van Damme N, Cuvelier C, et al. Immunomodulatory effects of anti-tumor necrosis factor alpha therapy on synovium in spondylarthropathy: histologic findings in eight patients from an open-label pilot study. Arthritis Rheum 2001; 44: 186-95.

18. Bosello S, Santoliquido A, Zoli A, Di Campli C, Flore R, Tondi P, et al. TNF-alpha blockade induces a reversible but transient effect on endothelial dysfunction in patients with long-standing severe rheumatoid arthritis. Clin Rheumatol 2008; 27: 833-9.

19. Orüm H, Pamuk GE, Pamuk ON, Demir M, Turgut B. Does anti-TNF therapy cause any change in platelet activation in ankylosing spondylitis patients? A comparative study. J Thromb Thrombolysis 2012; 33: 154-9.

20. Ambrosino P, Tasso M, Lupoli R, Di Minno A, Baldassarre D, Tremoli E, et al. Non-invasive assessment of arterial stiffness in patients with rheumatoid arthritis: a systematic review and meta-analysis of literature studies. Ann Med 2015; 47: 457-67.

21. Mäki-Petäjä KM, Hall FC, Booth AD, Wallace SM, Yasmin, Bearcroft PW, et al. Rheumatoid arthritis is associated with increased aortic pulse-wave velocity, which is reduced by anti-tumor necrosis factor-alpha therapy. Circulation 2006; 114: 1185-92.

22. Dulai R, Perry M, Twycross-Lewis R, Morrissey D, Atzeni F, Greenwald S. The effect of tumor necrosis factor- $\alpha$ antagonists on arterial stiffness in rheumatoid arthritis: a literature review. Semin Arthritis Rheum 2012; 42: 1-8.

23. Galarraga B, Khan F, Kumar P, Pullar T, Belch JJ. Etanercept improves inflammation-associated arterial stiffness in rheumatoid arthritis. Rheumatol (Oxford) 2009; 48: 1418-23.

24. Avram C, Drăgoi RG, Popoviciu H, Drăgoi M, Avram A, Amaricăi E. Association between arterial stiffness, disease activity and functional impairment in ankylosing spondylitis patients: a cross-sectional study. Clin Rheumatol 2016; 35: $2017-22$ 